UDC $543.79: 622.341 .1: 546.72: 543.21$ 論 文

\title{
三塩化チタン還元，有機指示薬判定法による 鉄鉱石中の全鉄定量方法*
}

$$
\begin{array}{llll}
\text { 佐 伯 正夫**. 西 坂 孝 } \text { 一** }^{* *} \\
\text { 岩 本 元 繁**. 安 達 }
\end{array}
$$

\author{
Determination of Total Iron in Iron Ores by Titanium \\ Trichloride Reduction-Organic Redox Indicator Method \\ Masao SAEKI, Kôichi Nishizaka, \\ Motoshige IWAMoto, and Akira ADACHI
}

\begin{abstract}
Synopsis:
In order to prevent the poliution of the drain-age from a chemical labolatory by $\mathrm{Hg}$, the authors proposed two new methods for the determination of total iron in iron ores in place of JIS method in which $\mathrm{Fe}(\mathrm{III})$ is reduced with $\mathrm{SnCl}_{2}$ and the excess of reductant is oxidized $\mathrm{HgCl}_{2}$. Those method are as follows:

For the purpose of verification analysis we established $\mathrm{TiCl}_{3}$ reduction-ITS indicator method in which the most part of $\mathrm{Fe}(\mathrm{III})$ is reduced with $\mathrm{SnCl}_{2}$, the remaining reduced with $\mathrm{TiCl}_{3}$ and the excess of $\mathrm{TiCl}_{3}$ is oxidized with $\mathrm{K}_{2} \mathrm{Cr}_{2} \mathrm{O}_{7}$ using indigo tetrasulfonic acid as the indicator. Dissolution of sample and titration of $\mathrm{Fe}$ (II) are the same as JIS method.

$\mathrm{Cu}(<2 \mathrm{mg})$ and $\mathrm{V}(<3 \mathrm{mg})$ do not interfere. Analytical results of iron ores by this method agreed closely with those by JIS method. $\left(d_{\mathrm{max}}=0.04 \% \mathrm{Fe}\right)$

For the purpose of rapid analysis was established $\mathrm{TiCl}_{3}$ reduction-NR indicator method in which main reagents used are $\mathrm{H}_{3} \mathrm{~PB}_{4}+\mathrm{H}_{2} \mathrm{SO}_{4}$, metallic $\mathrm{Al}$ and neutral red indicator in place of $\mathrm{HCl}, \mathrm{SnCl}_{2}$ and ITS indicator in the former method, respectively. $\mathrm{Sn}$ and $\mathrm{V}(>1 \cdot 2 \mathrm{mg})$ interfere. Analytical results of iron ores without interfering elements by the later are similar to the former.
\end{abstract}

(Received March 6, 1974)

\section{1. 緒言}

環境污染の問題はここ数年来社会の重大な関心を呼び 企業の公害対策は企業存立の最大要素として定着される ようになった．製鉄所における化学分析も例外ではあり えず，それぞれ大きな努力を注いでいるものの，最大の 関心事は，水銀㦈問題であろう.すなわち現行の JIS に よる鉄鉣石の全鉄定量方法"1) には塩化第二水銀の使用が 定められており，全鉄定量後の廃液処理については，各 分析所とも，少なくない負担となっている.

今回，当所において，水銀塩不使用の鉄鉱石中の全鉄 定量方法について検討を行ない, $\mathrm{Fe}(\mathbf{I})$ の還元に $\mathrm{TiCl}_{3}$ を用い， $\mathrm{Fe}(\mathbf{I})$ を酸化せずに $\mathrm{Ti}(\mathbf{I})$ のみを定量的に 酸化するために有機系の酸化䢬元指示薬を用い，以降の 操作を現行 JIS と同じ重クロム酸カリウム滴定法により 良好に定量できることに成功したのでてこに報告する.

\section{2. 定量方法の選択}

JIS 鉄鉱石中全鉄定量法には水銀塩を使用しない，硫 化水素還元法2）も决められている. この方法は有害な $\mathrm{H}_{2} \mathrm{~S}$ を使用するため操作が複雑となり, 分析に長時間を 要することなどから国内ではほとえど用いられていな い. その他水銀塩を使用しない鉄の定量方法としては, $\mathrm{Fe}$ (I) を還元滴定する方法3)， $\mathrm{Fe}\left(\right.$ II)を $\mathrm{SO}_{2}$ または, 亜鉛アマルガムで還元後酸化滴定する方法3)，および EDTA により錯滴定する方法3)，などがある. しかしこ れらの方法は妨害成分が多いか，または操作が複雑なこ となどから特别な目的以外には実用されていない。畑 ら")，は脇野ら5，の Al 還元法における Ti の妨害を防

* 昭和 48 年 10 月本会講演大会にて一部発表 昭和49年 3 月 6 日受付

** 新日本製鉄 $($ 株) 压烟製鉄所 
止するため， Al で還元された $\mathrm{Ti}$ をタングステン酸を指 示薬として酸化した. この方法はタングステン酸が变色 する酸化還元電位が低く，ほかの共存元素の妨害が多い． われわれは, 畑ら4)，の方法をるとに, 試料溶液中の $\mathrm{Fe}$ （II）を過剩の還元刘で還元し，還元威の過剩分を指 示薬を用いて定量的に酸化後, $\mathrm{Fe}$ (II) を酸化滴定する 方法に着目した。そして，この過剩の還元㘊および酸化 電位の比較的低い共存物質を，できるだけ定量的に酸化 し， しかも $\mathrm{Fe}(\mathbb{I})$ を酸化しない電位で変色する指示薬 を見出すため，おもな酸化，還元剂および指示薬の電位 を調查した、すなわち，酸化戍および還元戍の電位につ

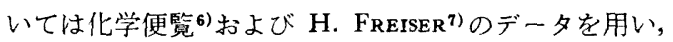
指示薬については石橋8)，吉村9)，および宗森10)の記事 を参考に，NERNST の式を用いてそれぞれの濃度と電位 の関係を計算した．その結果を Fig. 1 に示す.

試料を JIS 法にしたがつて分解した場合の酸化罢元電 位は Fig. 1，(2)および(8)式の電位が近似でき, 指示 薬としてはインジゴテトラスルホン酸（以後 ITS と略 す）が適している。この場合指示薬の変色電位 $0.36 \mathrm{~V}$ では, $-\log [\mathrm{Fe}$ (I) $/ \mathrm{Fe}$ (I) $] \fallingdotseq 5.5$ となり $\mathrm{Fe}$ (II) を酸 化することなく, $\mathrm{Sn}(\mathbb{I}), \mathrm{Ti}(\mathbb{I})$ および指示薬の変色 電位より低い共存物質を酸化することができる。また $\mathrm{Fe}$ (III) の還元に, $\mathrm{Sn}(\mathbb{I})$ または $\mathrm{Ti}(\mathbb{I})$ のいずれも 使用できることになるが， Ti は加水分解して 沈殿を生

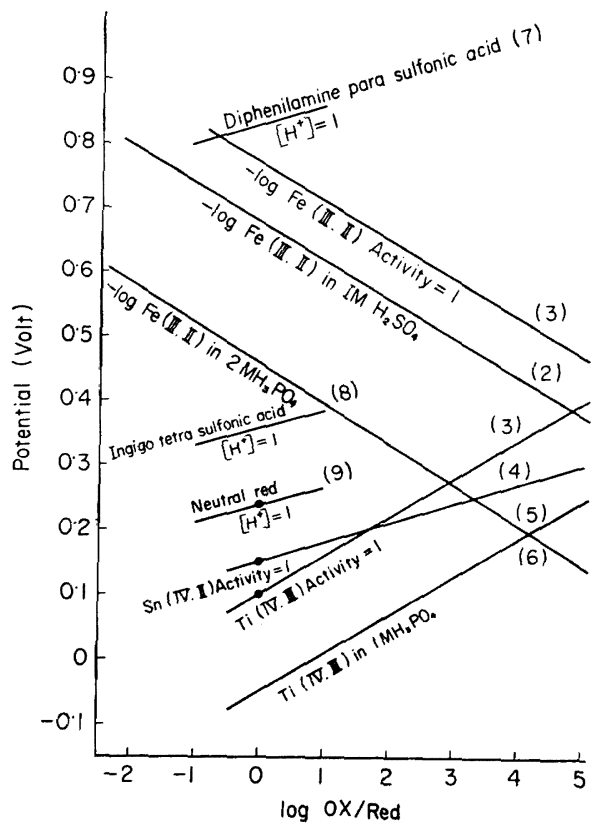

Fig. 1. Equilibrium diagram of $\mathrm{Fe}(\mathbb{I}, \mathbb{I}) . \mathrm{Sn}(\mathbb{N}$, II), $\mathrm{Ti}(\mathbb{V}, \mathbb{I})$ and organic indicators.
じるので多量には使用することができない．また後述す るように $\mathrm{Sn}(\mathbb{I})$ は酸化速度が拈そい，そこで大部分の $\mathrm{Fe}(\mathbb{I I})$ を $\mathrm{Sn}(\mathbb{I})$ で還元したのち, 残りの $\mathrm{Fe}(\mathbb{I I})$ の みを $\mathrm{Ti}(\mathbb{I I})$ で還元することとした.

JIS の試料分解法は長時間かかるため, 工程管理分析 としては旧 JIS'1) の $\mathrm{H}_{2} \mathrm{SO}_{4}$ と $\mathrm{H}_{3} \mathrm{PO}_{4}$ による分解法が よく用いられる.ここでは, Fe の酸化還元電位は Fig. $1(6)$ および (9) 式が近似でき, 指示薬としてニュート ラルレッド（以後 NR と略す）を使用することができ る. この場合指示薬の変色電位 $0 \cdot 24 \mathrm{~V}$ における $-\mathrm{log}$ $[\mathrm{Fe}($ III $) / \mathrm{Fe}(\mathbb{I})]=3.5$ となり, $\mathrm{Fe}$ の酸化は前述の ITS 指示薬法にくらべていくぶん増加する，鉄の還元绪とし て Sn（II）を使用した場合は指示薬が変色しないので， 金属 $\mathrm{Al}$ を使用することとした，そして還元後滴定まで に $\mathrm{Fe}$ (II) が空気酸化されるので補助還元戍として $\mathrm{Ti}$ （III）を使用することとした。

\section{ITS 指示薬による全鉄定量法}

\section{$3 \cdot 1$ 定量法の概要}

試料は JIS1) にしたがい $\mathrm{HCl}$ で分解し，末分解残渣 は $\mathrm{K}_{2} \mathrm{~S}_{2} \mathrm{O}_{7}$ で融解する. この試料溶液に $\mathrm{SnCl}_{2}$ 溶液を 加えて大部分の $\mathrm{Fe}(\mathbb{I})$ を還元し, 残りの $\mathrm{Fe}$ (III)を小 過剩の $\mathrm{TiCl}_{3}$ 溶液で還元する. ITS を指示薬として過 剩の $\mathrm{TiCl}_{3}$ を酸化後, $\mathrm{N} / 10 \mathrm{~K}_{2} \mathrm{Cr}_{2} \mathrm{O}_{7}$ 標準溶液で $\mathrm{Fe}$ (II) を酸化滴定する.

\section{$3 \cdot 2 \cdot 1$ 主要試薬}

(1) 混酸: $\mathrm{H}_{2} \mathrm{SO}_{4} 3 . \mathrm{H}_{3} \mathrm{PO}$, 3. 水 14 の割合で混 合する.

（2）ITS 指示薬：インジゴテトラスルフォン酸カリ ウムの $0.1 \mathrm{~W} / \mathrm{V} \%$ 溶液。

(3) $\mathrm{Fe}($ III) 溶液: 試薬 1 級の鉄粉 (Mn. Cu. As 各 $0.001 \%$ 以下) $26 \mathrm{~g}$ を $\mathrm{HCl} 300 \mathrm{ml}$ に溶解し $\mathrm{H}_{2} \mathrm{O}_{2}$ で $\mathrm{Fe}$ (II) を $\mathrm{Fe}$ (II) に酸化後, 加熱して $\mathrm{H}_{2} \mathrm{O}_{2}$ を分解し てから全量を $2.5 l$ にうすめた、この溶液の $\mathrm{Fe}(\mathbf{I})$ 含 有量は，JIS1) で定量した結果，

$25 \cdot 00 \mathrm{~m} l=\mathrm{Fe}$ ( II ) $241 \cdot 12 \mathrm{mg}=\mathrm{N} / 10 \mathrm{~K}_{2} \mathrm{Cr}_{2} \mathrm{O}_{7}$

$45 \cdot 50 \mathrm{ml}$ 相当であつた.

（4）シシフェニルアミンスルホン酸溶液：ジフェニル アミンスルホン酸 $\mathrm{Na}$ 塩 $0.2 \mathrm{~W} / \mathrm{V} \%$ 水溶液.

(5) $\mathrm{N} / 10 \mathrm{~K}_{2} \mathrm{Cr}_{2} \mathrm{O}_{7}$ 標潐溶液： $110^{\circ} \mathrm{C}$ で乾燥した標 準試薬 $\mathrm{K}_{2} \mathrm{Cr}_{2} \mathrm{O}_{7} 4.9034 \mathrm{~g}$ を水で溶解して正確に $1 /$ と する.

(6) $\mathrm{MnSO}_{4} 4 \%$ 溶液：硫酸マンガン $40 \mathrm{~g}$ を $\mathrm{H}_{2} \mathrm{SO}_{4}$ $(1+1) 5 \mathrm{~m} l$ と水で溶解し $1 l$ とする.

(7) $\mathrm{SnCl}_{2}$ 溶液：結晶塩化第一す寸゙，100 $\mathrm{g}$ を塩酸 
Table 1. Effect of $\mathrm{Mn}$ (II) and other elements.

\begin{tabular}{|c|c|c|c|c|c|c|c|c|c|}
\hline Added elements & \multirow{2}{*}{ Non added } & \multicolumn{4}{|c|}{$\operatorname{Mn}(\mathbb{I})$} & \multicolumn{2}{|c|}{$\mathrm{Ca}(\mathbb{I})$} & \multicolumn{2}{|c|}{$\mathrm{Al}(\mathbb{I})$} \\
\hline Added mg & & $0 \cdot 2$ & $1 \cdot 0$ & $5 \cdot 0$ & $50 \cdot 0$ & $1 \cdot 0$ & $5 \cdot 0$ & $1 \cdot 0$ & $5 \cdot 0$ \\
\hline $\begin{array}{l}\text { Difference } \\
\mathrm{m} l\left(\mathrm{~N} / 10 \quad \mathrm{~K}_{2} \mathrm{Cr}_{2} \mathrm{O}_{7}\right)\end{array}$ & $\begin{array}{l}+0 \cdot 08 \\
+0 \cdot 10\end{array}$ & 0 & 0 & 0 & 0 & +0.08 & +0.08 & $+0 \cdot 08$ & $0 \cdot 10$ \\
\hline
\end{tabular}

$200 \mathrm{ml}$ に溶解し少量の金属すずを加えて水で $1 l$ にう すめる.

(8) $\mathrm{TiCl}_{3}$ 溶液 $\mathrm{A}$ : 三塩化チタン溶液（JIS K 8401 相当品) $\mathrm{HCl}(1+1)$ で約 10 倍にうすめる.

(9) $\mathrm{TiCl}_{3}$ 溶液 $\mathrm{B}: \mathrm{TiCl}_{3}$ 溶液 $\mathrm{A}$ を使用のつど水で 的 10 倍にうすめる.

\section{$3 \cdot 2 \cdot 2 \mathrm{Mn}$ の効果}

溶液中の $\mathrm{Mn}$ が酸化還元滴定に微妙な影響をおよほ すことがよくあるので，その影暗を検討するため実験し た. $\mathrm{Fe}$ (I) 溶液 $25.00 \mathrm{ml}$ に $\mathrm{HCl} 10 \mathrm{ml}$ を加え水で液 量 $50 \sim 60 \mathrm{ml}$ とする. 約 $90^{\circ} \mathrm{C}$ に加熱しわずかに $\mathrm{Fe}$ （I）の黄色が残る程度に $\mathrm{SnCl}_{2}$ 溶液を加える. ITSを 指示薬として加え, $\mathrm{TiCl}_{3}$ 溶液を谪加して $\mathrm{Fe}($ I $)$ を還 元し, 過剩の $\mathrm{Ti}(\mathbf{H})$ を, $\mathrm{K}_{2} \mathrm{Cr}_{2} \mathrm{O}_{7}(0.1 \mathrm{~W} / \mathrm{V} \%)$ で酸 化する. 以下 JIS にしたがつて，N/10 $\mathrm{K}_{2} \mathrm{Cr}_{2} \mathrm{O}_{7}$ で Fe （I）を谪定した. その結果つねに $0.1 \mathrm{ml}$ 近辺の過大 な滴定值が生ずる.この原因として ITS の発色時にお いて末酸化の Ti（保）が残っていると推定された.

そこで鉄鉣石中に含をれる金属元素数種を $\mathrm{Fe}$ (II) 溶 液に加え，同じく操作し，T．Fe を定量してみた結果 Mn（I）の添加により正確な定量值がえられた．このこ とから $\mathrm{Mn}(\mathbf{I})$ が $\mathrm{Ti}$ (II) の酸化を促進したものと考 えられる. Mn は少量の添加で効果があり, 多量の存在 も支障とはならない，Ca，Al などは効果がなかった。 これらの結果を Table 1 に示す.

\section{$3.2 \cdot 3 V の$ 影響とその妨害除去対策}

Vの酸化還元電位は酸濃度によつて大きく变化する ${ }^{1}$. $\mathrm{Fe}$ (I) の還元以後の操作における Vの影響について酸 濃度および Mn 添加量を变えて検討した結果を Fig. 2 に示す。

Fig. 2 より $\mathrm{HCl}$ 濃度が高い場合はVの影響が大きい が, $\mathrm{HCl} 0.3 \mathrm{~N}$ ではその影響が少なく, Mn $2 \mathrm{mg}$ の添 加で $2 \cdot 0 \mathrm{mg}$ までの Vが, Mn $50 \mathrm{mg}$ の添加で 3.0mg までのVが妨害しないことがわかつた。

\section{$3.2 .4 \mathrm{Cu}$ の影響とその妨害除去対策}

JIS 法")，では Cu は負誤差生成の原因となり，谪定 時液温が高いほど妨害度合いは大きくなることが知られ ている.われわれはこの原因について検討し $\mathrm{Cu}$ の負誤

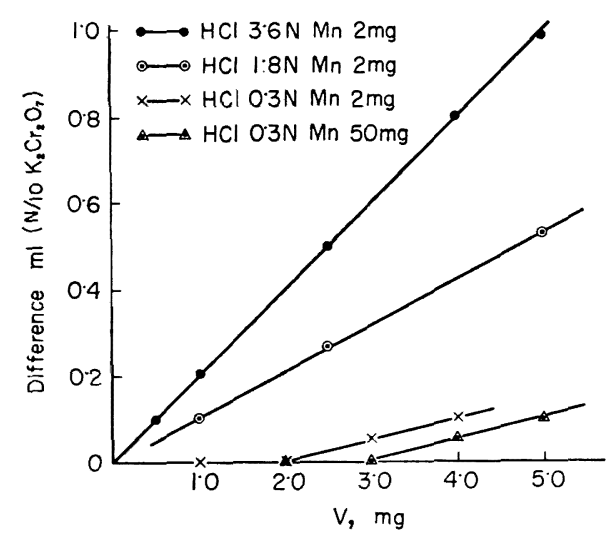

Fig. 2. Effects of $\mathrm{V}$ and $\mathrm{HCl}$ concentration.

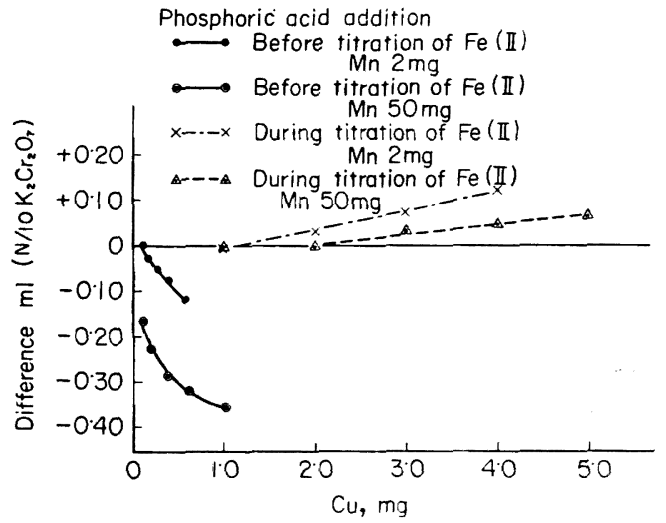

Fig. 3. Effects of $\mathrm{Cu}, \mathrm{Mn}$ and timing of $\mathrm{H}_{3} \mathrm{PO}_{4}$ addition.

差妨害は, $\mathrm{Cl}$-の共存を必須とし液の電位の低い場合に おいて生成すること, および $\mathrm{P}_{2} \mathrm{O}_{7}$ イオンの添加はその 傾向を增大させる作用があることを確めた：そうして $\mathrm{Fe}(\mathbb{I})$ の酸化谪定開始時に $\mathrm{H}_{3} \mathrm{PO}_{4}$ を加えず墑定が全 体の $1 / 10$ 以上進行したのち $\mathrm{H}_{3} \mathrm{PO}_{4}$ を加えると $\mathrm{Cu}$ よる負誤差を生じないことを知った。（未発表）

今回は， $\mathrm{Cu}$ の妨害と Mn の添加量および混酸の添加 時期の関係について検討し，その結果を Fig. 3 に示す. Fig. 3 より, $\mathrm{Fe}$ (II) を滴定する前に混酸を加えた場合 
は， $\mathrm{Cu}$ の妨害が負誤差として大きく現われるが， $\mathrm{Fe}$ （II）の滴定途中で混酸を加えた場合は，Cu はわずかに 正誤差を示ししかも $\mathrm{Mn}$ 共存量の多いほうが $\mathrm{Cu}$ の妨 害が小さいことがわかつた。 また混酸の添加時期は N/ $10 \mathrm{~K}_{2} \mathrm{Cr}_{2} \mathrm{O}_{7}$ 全消費量の $1 / 10$ が滴加されたのち, 終点 までの間でよい。

\section{$3 \cdot 2 \cdot 5$ その他の物質の影響}

最近の鉄鉣石には，本法の妨害となる成分を含むこと は少ないが，鉄鉱石に含まれ，鉄の定量を妨害しそうな
物質および分析過程で添加または混入する機会のある物 質について検討し，その結果を Table 2 に示す.

JIS 法では As の妨害がないとされているが，本法で は $\mathrm{Mn}(\mathbb{I})$ の共存が多くなると妨害する. W および Mo も同じ傾向を示し, Pt は JIS 法と同じく妨害とな る.

\section{$3 \cdot 2 \cdot 6$ その他の検討}

本法において, $\mathrm{SnCl}_{2}$ による $\mathrm{Fe}$ (II) の還元操作から 過剩 $\mathrm{Ti}(\mathbf{I})$ の酸化操作までは $\mathrm{HCl}$ 濃度 $3.6 \mathrm{~N} \sim 0.3 \mathrm{~N}$

Table 2. Effects of various elements on ITS method.

\begin{tabular}{|c|c|c|c|c|}
\hline Added elements & Added (mg) & Mn Added (mg) & $\begin{array}{l}\text { Difference }(\mathrm{ml}) \\
\left(\mathrm{N} / 10 \mathrm{~K}_{2} \mathrm{Cr}_{2} \mathrm{O}_{7}\right)\end{array}$ & Note \\
\hline \multirow{2}{*}{ As (I) } & $\begin{array}{l}0 \cdot 5 \\
0 \cdot 75 \\
1 \cdot 00\end{array}$ & $\begin{array}{l}2 \\
2 \\
2\end{array}$ & $\begin{array}{l}0 \\
0 \\
0\end{array}$ & \\
\hline & $\begin{array}{l}0 \cdot 5 \\
0 \cdot 75 \\
1 \cdot 00\end{array}$ & $\begin{array}{l}50 \\
50 \\
50\end{array}$ & $\begin{array}{l}+0 \cdot 05 \\
+0 \cdot 10 \\
+0.18\end{array}$ & \\
\hline \multirow{2}{*}{ Mo ( II) } & $\begin{array}{l}1 \cdot 0 \\
5 \cdot 0\end{array}$ & $\begin{array}{l}2 \\
2\end{array}$ & $\begin{array}{l}0 \\
0\end{array}$ & \\
\hline & $\begin{array}{l}1 \cdot 0 \\
5 \cdot 0\end{array}$ & $\begin{array}{l}50 \\
50\end{array}$ & $\begin{array}{l}+0 \cdot 10 \\
+0 \cdot 35\end{array}$ & \\
\hline \multirow{2}{*}{ W ( II) } & $\begin{array}{l}1 \cdot 0 \\
5 \cdot 0\end{array}$ & $\begin{array}{l}2 \\
2\end{array}$ & $\begin{array}{l}0 \\
-0.03\end{array}$ & \\
\hline & $\begin{array}{l}1 \cdot 0 \\
5 \cdot 0\end{array}$ & $\begin{array}{l}50 \\
50\end{array}$ & $\begin{array}{l}0 \\
+0 \cdot 30\end{array}$ & \\
\hline $\mathrm{Se}(\mathrm{IV})$ & $\begin{array}{l}1 \cdot 0 \\
5 \cdot 0\end{array}$ & $\begin{array}{l}2 \\
2\end{array}$ & - & $\begin{array}{l}\text { Titration of } \mathrm{Fe}(\mathbb{I}) \text { is } \\
\text { impossible }\end{array}$ \\
\hline Pt (IV) & $\begin{array}{l}1 \cdot 0 \\
2 \cdot 0 \\
5 \cdot 0\end{array}$ & $\begin{array}{l}2 \\
2 \\
2\end{array}$ & $\begin{array}{l}+0.10 \\
+0.20 \\
+0.50\end{array}$ & \\
\hline $\mathrm{Ni}$ (I) & $5 \cdot 0$ & 2 & 0 & \\
\hline $\mathrm{Cr}(\mathrm{H})$ & $5 \cdot 0$ & 2 & 0 & \\
\hline $\mathrm{NaCl}$ & $\begin{array}{l}1000 \\
5000\end{array}$ & $\begin{array}{l}2 \\
2\end{array}$ & $\begin{array}{l}0 \\
0\end{array}$ & \\
\hline $\mathrm{NH}_{4} \mathrm{HF}_{2}$ & $\begin{array}{r}500 \\
1000\end{array}$ & $\begin{array}{l}2 \\
2\end{array}$ & $\begin{array}{c}0 \\
-0 \cdot 02\end{array}$ & \\
\hline $\mathrm{H}_{3} \mathrm{PO}_{4}$ & $\begin{array}{r}5 \cdot 0 \\
10 \cdot 0\end{array}$ & $\begin{array}{l}2 \\
2\end{array}$ & $\begin{array}{l}0 \\
0\end{array}$ & \\
\hline $\mathrm{H}_{3} \mathrm{BO}_{3}$ & $\begin{array}{l}200 \\
500\end{array}$ & $\begin{array}{l}2 \\
2\end{array}$ & - & $\begin{array}{l}\text { Oxidation of } \mathrm{Ti}(\boldsymbol{I}) \\
\text { is very slow }\end{array}$ \\
\hline $\mathrm{HClO}_{4}$ & $\begin{array}{l}1 \cdot 0 \\
2 \cdot 0\end{array}(\mathrm{ml})$ & $\begin{array}{l}2 \\
2\end{array}$ & $\begin{array}{l}0 \\
0\end{array}$ & \\
\hline $\mathrm{Kl}$ & $5 \cdot 0$ & 2 & - & The titraticn of $\mathrm{Fe}(\mathbb{I})$ \\
\hline $\mathrm{KBr}$ & $5 \cdot 0$ & 2 & - & \\
\hline
\end{tabular}


で分析值に影響しないが，塩酸濃度が低いほど $\mathrm{Ti}$ (II) の酸化速度は早いようであったまたVの妨害を防止す るために，塭酸 $0.3 \mathrm{~N}$ 近くで上記操作を行なつた場合は 滴定時沈殿物が 生成するので硫酸を加え酸濃度を高く する必要があつた． また $\mathrm{SnCl}_{2}$ による $\mathrm{Fe}(\mathbf{I})$ の還元 操作から過剩の $\mathrm{Ti}(\mathbf{I})$ の酸化終了までの行程は液温が 高いほど反応が早く，50C 以下では操作がしにくくな る.

$\mathrm{Sn}$ (I ) で $\mathrm{Fe}$ (II) の全量を邆元したかつたのはつぎ の理由による. Fig. 1 の酸化還元電位でみると, Sn (I) はITS 指示薬を無色化できるはずであるが，実際には $\mathrm{Fe}$ (I) の還元を終り過剩の $\mathrm{SnCl}_{2}$ を加えた状態でも ITS 指示薬は，青色〜黄緑色となり無色とはならない. $\mathrm{Ti}$ (I) は ITS 指示薬に対し鮮明な変色がある。 また $\mathrm{Fe}$ (I) の全量を $\mathrm{Sn}$ (I) で還元し少過剩を加え, さら に $\mathrm{TiCl}_{3}$ 液で ITS 指示薬を無色としたのち, $\mathrm{K}_{2} \mathrm{Cr}_{2} \mathrm{O}_{7}$ 溶液を加え ITS を青色とし，この液について $\mathrm{Fe}(\mathbb{I})$ の酸化滴定を $\mathrm{K}_{2} \mathrm{Cr}_{2} \mathrm{O}_{7}$ で行なうときは, $\mathrm{Sn}(\mathbb{I})$ に原因 すると思われる過大滴定值がつねに生ずる．

試料の分解に $\mathrm{NH}_{4} \mathrm{HF}_{2}$ を使用する方法は12) 工程管理 分析などによく用いられる方法である.この方法はビー カーからの Fe の溶出，および試料の不完全分解による 誤差が考えられる．そこでこれらについて実験した結果 を Table 3，および Table 4 に示す. この結果より上 記のふたつの $\mathrm{Fe}$ は大きな誤差原因とはならないが，精 密を要求される分析では，これらの誤差を無視すること はできない.なお $\mathrm{NH}_{4} \mathrm{HF}_{2}$ の使用により，内面がザラ ザラになったビーカーは $\mathrm{Fe}$ (II) の損失が多いが, $\mathrm{SnCl}_{2}$ で $\mathrm{Fe}$ (I) に還元しておけば $\mathrm{Fe}$ の損失を防止できるこ

Table 3. Amount of dissolved from glass-beaker with $\mathrm{HCl}$ and $\mathrm{NH}_{4} \mathrm{HF}_{2}$.

\begin{tabular}{c|c|c|c}
\hline Beaker maker & A & B & C \\
\hline \multirow{3}{*}{ Fe mg } & 0.044 & 0.032 & 0.060 \\
& 0.032 & 0.060 & 0.040 \\
& 0.036 & 0.040 & 0.060 \\
\hline
\end{tabular}

とを経験している.

\section{3 .3 確立した定盘方法}

\section{3 .1 定量操作}

以上検討の結果，ITS 指示薬法による鉄鉱石中の全鉄 定量法をつぎのように定めた.

(1) 試料 $0.4000 \mathrm{~g}$ をビーカーにはかりとり, $\mathrm{HCl}$ $\mathrm{O}_{4}(1+1) 5 \mathrm{ml}$ を加え加熱乾固させる. 冷却後 $\mathrm{HCl}(2+$ 1) $30 \mathrm{ml}$ を加え熱溶解する. 溶解後温水 $50 \mathrm{ml}$ でうす め，ろ紙 (NO 5B) を用いてろ過，洗浄する．万液およ び洗液は加熱濃縮して 保存する. 残椬は乾燥, 灰化後 $\mathrm{HF}$ により $\mathrm{SiO}_{2}$ を分解し $\mathrm{K}_{2} \mathrm{~S}_{2} \mathrm{O}_{7}$ で融解後 $\mathrm{HCl}(1+$ 100) に溶解し， $\mathrm{NH}_{4} \mathrm{OH}$ で $\mathrm{Fe}$ を水酸化物として沈殿 させ， $\mathrm{Pt}$ と分離して $\mathrm{HCl}(1+10)$ に溶解し主液に加え る.

（2）この試料溶液に $\mathrm{KMnO}_{1}(3 \%) 2 \sim 3$ 滴加え，約 $50 \mathrm{ml}$ に濃箱する. 液温約 $90^{\circ} \mathrm{C}$ で $\mathrm{SnCl}_{2}$ 溶液を滴加 して $\mathrm{Fe}$ (II) の黄色がわずかに残る程度まで $\mathrm{Fe}$ (II)を 還元する.

ITS 指示薬 2〜3 滴加え，無色となるまで $\mathrm{TiCl}_{3}$ 溶 液Aを滴加する，つぎに ITS が青色を呈するまで過剩 の $\mathrm{Ti}(\mathbb{I I})$ を $\mathrm{K}_{2} \mathrm{Cr}_{2} \mathrm{O}_{7}(0.1 \mathrm{~W} / \mathrm{V} \%)$ をビューレットを 用いて加え, 酸化する。

（3）水を加えて全液量を約 $300 \mathrm{ml}$ にうすめ，混酸 $30 \mathrm{ml}$ およびジフェニルアミンスルホン酸溶液 3〜4滴 加え $\mathrm{N} / 10 \mathrm{~K}_{2} \mathrm{Cr}_{2} \mathrm{O}_{7}$ 標準溶液で鉄を滴定する.

備考 1 . この方法の適用範囲は $\mathrm{V} 0.2 \mathrm{mg}$ 以下, $\mathrm{Cu}$ $0.1 \mathrm{mg}$ 以下, As $1 \mathrm{mg}$ 以下でかつ $\mathrm{Mn} 2 \mathrm{mg}$ 以下の試 料に適用する.

備考 2. この方法は, 試料の分解に $\mathrm{SnCl}_{2}$ を用いる方 法1および， ${ }^{11} H_{4} \mathrm{HF}_{2}$ を用いる方法12)を併用して行なっ てもよい. このとき $\mathrm{NH}_{4} \mathrm{HF}_{2}$ の添加量は $10 \mathrm{~W} / \mathrm{V} \%$ と して $5 \mathrm{ml}$ 以下とする. 試料の分解が終つたのち, 過、 ンガン酸カリウム溶液 $(3 \mathrm{~W} / \mathrm{V} \%) 2 \sim 3$ 滴加え，必要に 応じて過酸化水素水 $(5 \%)$ を加え, 黄色を呈させる.

水を加えて液量約 $50 \mathrm{ml}$ とし, 加熱して $90^{\circ} \mathrm{C}$ とし $\mathrm{SnCl}_{2}$ 溶液を滴加して淡黄色を呈するまで $\mathrm{Fe}(\mathbf{I})$ を還

Table 4. Results of acid-insoluble $\mathrm{Fe}$ with $\mathrm{HCl}$ and $\mathrm{NH}_{4} \mathrm{HF}_{2}$.

\begin{tabular}{l|l}
\hline \multicolumn{1}{c|}{ Sample } & Fe \% \\
\hline Marcona & 0.010 \\
Marcona pellet & 0.007 \\
Hamersley & 0.007 \\
Bandey & 0.014 \\
Santa barbara & 0.033 \\
Romeral & 0.025 \\
Bairadila & 0.008 \\
\hline
\end{tabular}

\begin{tabular}{l|c}
\hline \multicolumn{1}{c|}{ Sample } & Fe \% \\
\hline Brazilian & $0 \cdot 019$ \\
Swaziland & $0 \cdot 014$ \\
Argalobo & $0 \cdot 010$ \\
Goldswarthy & $0 \cdot 010$ \\
Port Redi & $0 \cdot 009$ \\
Santa Fe & $0 \cdot 015 \sim 0 \cdot 03$ \\
Mt. Newman & $0 \cdot 007$ \\
\hline
\end{tabular}


元する. ITS 指示薬を 2〜3 滴加え無色となるまで Ti $\mathrm{Cl}_{3}$ 溶液 $\mathrm{A}$ を滴加し, 以下主文の方法により操作する.

備考 $3 . \mathrm{V}$ 共存量 $0.2 \sim 2 \mathrm{mg}$ の試料にあってはつぎ のように操作する. 試料溶液を $\mathrm{NH}_{4} \mathrm{OH}$ 水で水酸化鉄 の沈殿を生成させ，つぎに $\mathrm{HCI}(1+1)$ を滴加して，わ ずかな濁りが残る程度をでの酸性として過剩に $5 \mathrm{ml}$ 加 える. 水で $100 \mathrm{ml}$ にうすめ, 沸点近くまで加熱する. $\mathrm{SnCl}_{2}$ で淡黄色となるまで $\mathrm{Fe}(\mathbb{I I})$ を還元し, ITS 指示 薬を 2 3 滴加え, $\mathrm{TiCl}_{3}$ 溶液 $\mathrm{B}$ を滴加し青色がうすれ はじめたならば滴加をやめ, $\mathrm{K}_{2} \mathrm{Cr}_{2} \mathrm{O}_{7}$ 溶液 $(0 \cdot 1 \mathrm{~W} / \mathrm{V} \%)$ を滴加し青色を呈させる. $\mathrm{H}_{2} \mathrm{SO}_{4}(1+1) 10 \mathrm{ml}$ を加え水 で $300 \mathrm{ml}$ にうすめ混酸 $30 \mathrm{ml}$ 党加㫕以下主文の方法に より滴定する.

$\mathrm{V}$ 共存量 2 3 $\mathrm{mg}$ の試料については, 上記操作のほ か, $\mathrm{SnCl}_{2}$ による $\mathrm{Fe}(\mathbb{I})$ の還元開始以前に $\mathrm{MnSO}_{4}$ 溶 液 $5 \mathrm{ml}$ を加えなければならない.

備考 4. $\mathrm{Cu}$ 共存量 0.1 I $\mathrm{mg}$ の試料では, $\mathrm{Ti}(\mathbb{I I}) の$ 酸化を終ったのち，水で約 $300 \mathrm{ml}$ にうすめ $\mathrm{N} / 10 \mathrm{~K}_{2}$
$\mathrm{Cr}_{2} \mathrm{O}_{7}$ を用い $\mathrm{Fe}($ II $)$ を滴定し, 約 $1 / 10$ の滴定後, 終 点亡でに混酸 $30 \mathrm{~m} l$ およびジフェニルアミンスルフォン 酸溶液を 3〜4 滴を加える. Cu l〜2 mg の試料では上 記操作のほか $\mathrm{SnCl}_{2}$ による $\mathrm{Fe}(\mathbb{I I})$ の還元開始以前に $\mathrm{NinSO}_{4}$ 溶液 $5 \mathrm{ml}$ を加えなければならない.

\section{4 実際試料の分析結果}

確立した分析法（しかし，Mnの添加ははぶいた）に より実際試料を分析し，JIS1)法と比較した結果を Table 5 に示す。 また各種標準試料を分析した結果を Ta'le 6 に示す.

これらの結果から本法は JIS1) 法とよく一致すること がわかる、また，たいていの鉱石は不純物として含有す る量の $\mathrm{Mn}$ 量で $\mathrm{Ti}(\mathbb{I I})$ の酸化促進の効果はあつた. しかし, JSS 802 酸化鉄のような試料も考えられるから Mn の添加は常に行なったほうがよい。

Table 6 の結果では標準值とよく一致しており $3 \cdot 3 \cdot 2$ 備考 4 の Cu 妨害除去対策も効果あることを確認した。

Table 5. Comparison of analytical results by ITS method to JIS method.

\begin{tabular}{|c|c|c|c|c|}
\hline \multirow{2}{*}{ Sample } & \multicolumn{3}{|c|}{$\mathrm{Fe} \%$} & \multirow{2}{*}{ Note } \\
\hline & JIS method A & ITS method B & Error & \\
\hline $\begin{array}{l}\text { Kiruna pellet } \\
\text { Marcona Slurry } \\
\text { Marcona pellet } \\
\text { Goldswarthy } \\
\text { Goa } \\
\text { Hamersley } \\
\text { Hamersley pellet } \\
\text { Chowgle } \\
\text { Bailadila } \\
\text { Bandecar } \\
\text { Brazilian } \\
\text { Marampa } \\
\text { Algarrobo } \\
\text { Mt. Newman } \\
\text { Miferma } \\
\text { Swaziland } \\
\text { Salgaoncar } \\
\text { Wabuska } \\
\text { Whyalla } \\
\text { Lamco } \\
\text { Krivoyrog } \\
\text { Port Redi } \\
\text { Robe River pellet } \\
\text { Foment } \\
\text { Geraldton } \\
\text { Agrawol } \\
\text { Savage River pellet }\end{array}$ & $\begin{array}{l}64 \cdot 80 \\
69 \cdot 78 \\
65 \cdot 72 \\
63 \cdot 61 \\
60 \cdot 98 \\
66 \cdot 20 \\
63 \cdot 49 \\
59 \cdot 34 \\
65 \cdot 65 \\
63 \cdot 00 \\
67 \cdot 88 \\
63 \cdot 25 \\
61 \cdot 25 \\
65 \cdot 15 \\
58 \cdot 40 \\
63 \cdot 61 \\
59 \cdot 00 \\
62 \cdot 20 \\
64 \cdot 85 \\
66 \cdot 32 \\
64 \cdot 30 \\
60 \cdot 00 \\
62 \cdot 77 \\
60 \cdot 80 \\
60 \cdot 04 \\
62 \cdot 05 \\
67 \cdot 40\end{array}$ & $\begin{array}{l}64 \cdot 80 \\
69 \cdot 78 \\
65 \cdot 72 \\
63 \cdot 65 \\
60 \cdot 98 \\
66 \cdot 24 \\
63 \cdot 45 \\
59 \cdot 31 \\
65 \cdot 65 \\
63 \cdot 03 \\
67 \cdot 91 \\
63 \cdot 25 \\
61 \cdot 25 \\
65 \cdot 18 \\
58 \cdot 43 \\
63 \cdot 61 \\
59 \cdot 00 \\
62 \cdot 24 \\
64 \cdot 85 \\
66 \cdot 28 \\
64 \cdot 30 \\
60 \cdot 00 \\
62 \cdot 77 \\
60 \cdot 77 \\
60 \cdot 04 \\
62 \cdot 08 \\
67 \cdot 36\end{array}$ & $\begin{array}{l}0 \\
0 \\
0 \\
0 \cdot 04 \\
0 \\
0 \cdot 04 \\
-0 \cdot 04 \\
-0 \cdot 03 \\
0 \\
0 \cdot 03 \\
0 \cdot 03 \\
0 \\
0 \\
0 \cdot 03 \\
0 \cdot 03 \\
0 \\
0 \\
0 \cdot 04 \\
0 \\
-0 \cdot 04 \\
0 \\
0 \\
0 \\
-0 \cdot 03 \\
0 \\
0 \cdot 03 \\
-0 \cdot 04\end{array}$ & $\mathrm{~V} 1 \cdot 2 \mathrm{mg}$ \\
\hline \multirow{2}{*}{$\begin{array}{l}\text { JSS } 802-1 \\
\text { IRON OXIDE }\end{array}$} & $69 \cdot 95$ & $70 \cdot 09$ & $0 \cdot 14$ & *Mn free \\
\hline & $69 \cdot 95$ & $69 \cdot 95$ & 0 & Mn lmg added \\
\hline$N=28$ & \multicolumn{3}{|c|}{ Eliminate $*$ data $\bar{d}=0.0033 \%$} & \\
\hline
\end{tabular}

A : Oxidation by $\mathrm{HgCl}_{2}$ B : Indicator (Indigo tetra Sulufonic acid) 
Table 6. Results of standard samples ITS method.

\begin{tabular}{|c|c|c|c|c|}
\hline Sample & $\begin{array}{c}\text { Standard value } \\
\text { T. Fe } \%\end{array}$ & T. $\mathrm{Fe} \%$ & Method & Error \\
\hline \multirow{2}{*}{$\begin{array}{l}\text { JSS } 800-1 \text { LOMPIN } \\
\text { Iron ore }\end{array}$} & \multirow{2}{*}{$\begin{array}{c}62 \cdot 85 \\
(\mathrm{Cu} 0 \cdot 064)\end{array}$} & $\begin{array}{l}62 \cdot 77 \\
62 \cdot 80\end{array}$ & A & $\begin{array}{l}-0 \cdot 08 \\
-0.05\end{array}$ \\
\hline & & $\begin{array}{l}62 \cdot 85 \\
62 \cdot 82\end{array}$ & B & $\begin{array}{l}0 \\
-0.03\end{array}$ \\
\hline \multirow{2}{*}{$\begin{array}{l}\text { JSS } 810-1 \text { TEXADA } \\
\text { Iron ore }\end{array}$} & \multirow{2}{*}{$\begin{array}{c}64 \cdot 87 \\
(\mathrm{Cu} 0 \cdot 046)\end{array}$} & $\begin{array}{l}64 \cdot 81 \\
64 \cdot 81\end{array}$ & $\mathrm{~A}$ & $\begin{array}{l}-0 \cdot 06 \\
-0.06 \\
\end{array}$ \\
\hline & & $\begin{array}{l}64 \cdot 84 \\
64 \cdot 88\end{array}$ & $\mathrm{~B}$ & $\begin{array}{l}-0.03 \\
+0.01\end{array}$ \\
\hline $\begin{array}{l}\text { JSS } 801 \text { INDIAN } \\
\text { Iron ore }\end{array}$ & $64 \cdot 66$ & $\begin{array}{l}64 \cdot 65 \\
64 \cdot 68\end{array}$ & A & $\begin{array}{l}-0 \cdot 01 \\
+0 \cdot 02\end{array}$ \\
\hline $\begin{array}{l}\text { BCS } 175 / \text { LIBELIAN } \\
\text { Iron ore }\end{array}$ & $63 \cdot 15$ & $\begin{array}{l}63 \cdot 19 \\
63 \cdot 14\end{array}$ & A & $\begin{array}{l}+0.04 \\
-0.01\end{array}$ \\
\hline
\end{tabular}

Method. A; $\mathrm{H}_{3} \mathrm{PO}_{4}$ is added before titration of $\mathrm{Fe}$ (II) Method. $\mathrm{B} ; \mathrm{H}_{3} \mathrm{PO}_{4}$ is added during titration of Fe(II)

\section{5 作業性}

試料分解法を標準的方法で行なうときは特に大きなメ リットはない，備考 2 の簡便分解法では約 10 分間の加 熱で十分に分解する試料が少なくないまた難分解性の 試料 (Santa Fe) でも労働負荷の軽減には大きな効果が ある. $\mathrm{SnCl}_{2}$ 添加以降 $\mathrm{Fe}(\mathbf{I})$ の酸化滴定終了までには 約 5 分間を要する. この所要時間は, 脇野5), 畑4)の方法 にくらべてきわめて短時間であるのみならず, JIS 法1) の 18 分にくらべてもすこぶる短時間である.

妨害成分に対する処理方法も畑4)の方法にくらべても はなはば簡単であり，Cu に対しては JIS 法)にくらべ ても許容限度が大きいこと，その操作の単純なことなど 作業性にすぐれている.

\section{NR 指示薬による全鉄定量法}

\section{1 定量法の概要}

試料を $\mathrm{H}_{2} \mathrm{SO}_{4} ， \mathrm{H}_{3} \mathrm{PO} 4$ および $\mathrm{HF}$ で分解し，酸濃度 を調節したのち金属 $\mathrm{Al}$ を用いて $\mathrm{Fe}(\mathbf{I})$ を還元する。 冷却後 NR 指示薬を加えてから $\mathrm{TiCl}_{3}$ 溶液で $\mathrm{Fe}($ II $)$ を還元する.ささらに NR を指示薬として過剩の $\mathrm{Ti}(\mathbf{I})$ を $\mathrm{K}_{2} \mathrm{Cr}_{2} \mathrm{O}_{7}$ で酸化後, $\mathrm{N} / 10 \mathrm{~K}_{2} \mathrm{Cr}_{2} \mathrm{O}_{7}$ 標準溶液で $\mathrm{Fe}$ (I) を酸化谪定する.

\section{2 定量法の検討}

$4 \cdot 2 \cdot 1$ 主要試薬

(1) $\mathrm{TiCl}_{3}$ 溶液 $\mathrm{A}$ : 三塩化チタン溶液（JIS K 8401 相当品）を $\mathrm{HCl}(1+1)$ で 10 倍にうすめる.

（2）金属 $\mathrm{Al}$ : 粒度 10〜20 mesh のフレーク状 $\mathrm{Al}$ で, Fe 0.1〜0.2\% 含むものがよい. しかし Cu を含む ものは使用できない，この試薬に含む Fe は空実験で補
正しなければならない.

(3) NR 指示薬 : ニュートテルレッド 0.05 W/V\% の水溶液, この溶液はかつ色びんに保存する.

（4）その他この実験に用いた試薬は 3.2 .1 と同じも のである.

\section{$4 \cdot 2 \cdot 2 \mathrm{Mn}($ II ) の効果}

ITS の場合は Mn（II）が存在しないと過剩の $\mathrm{Ti}(\mathbb{I})$ を完全に酸化できなかった～そこでNR 法についても 同様なことがありうるか検討してみた． $\mathrm{Fe}($ III ) 溶液 (3.2.1 に示したもの) $25 \cdot 0 \mathrm{ml}$ を採取しこれに $\mathrm{HCl} 5$ $\mathrm{m} l \mathrm{H}_{2} \mathrm{SO}_{4}(1+1) 15 \mathrm{ml} \mathrm{H}_{3} \mathrm{PO}_{4} 10 \mathrm{ml}$ を加え水で約 100 $\mathrm{m} l$ にうすめ，これに金属 $\mathrm{Al} 1.5 \mathrm{~g}$ を加えて $\mathrm{Fe}(\mathbb{I})$ を還元する. Al の溶解が終ったのち泠却し， NR を指 示薬とし少過剩の $\mathrm{TiCl}_{3}$ 溶液を加えて残る $\mathrm{Fe}(\mathbb{I})$ を還 元する. 過剩の $\mathrm{Ti}$ (II) を $\mathrm{K}_{2} \mathrm{Cr}_{2} \mathrm{O}_{7}$ 溶液 $(0.1 \mathrm{~W} / \mathrm{V} \%)$ で酸化しこれを約 $200 \mathrm{ml}$ にうすめ, JIS 法に準じて, $\mathrm{N} / 10 \mathrm{~K}_{2} \mathrm{Cr}_{2} \mathrm{O}_{7}$ で滴定した.

その結果約 $0.1 \mathrm{~m} l$ 近辺の過大滴定値となった.この 原因として $3 \cdot 2 \cdot 2$ と同じように Ti (III) の酸化末了と考 えられた. $\mathrm{Fe}$ (III) 溶液に $\mathrm{Mn}(\mathbb{I})$ を添加することによ り正確な結果がえられた. 以上の結果を Table 7 に示 す.

以下の実験では試料溶液の準備はすべて JSS 801-1 イ

Table 7. Effect of $\mathrm{Mn}$ (11).

\begin{tabular}{l|c|c|c}
\hline $\mathrm{Mn}(\mathbb{I})$ Added (mg) & 0 & 0.2 & 1.0 \\
\hline $\begin{array}{l}\text { Difference } \\
\mathrm{N} / 10 \mathrm{~K}_{2} \mathrm{Cr}_{2} \mathrm{O}_{7}(\mathrm{~m} l)\end{array}$ & $+0 \cdot 10$ & 0 & 0 \\
\hline
\end{tabular}


ンド鉄鉱石その他の鉄鉱石を用いており，これらの鉄鉱 石中には多少なりとも $\mathrm{Mn}$ を含むので，とくに Mn を 加える操作はおこなっていない。

\section{$4 \cdot 2.3$ 金属 $\mathrm{Al}$ による $\mathrm{Fe}$ の還元}

金属 $\mathrm{Al}$ による $\mathrm{Fe}(\mathbb{I})$ の還元条件について検討する ため，JSS 801-1 インド鉱石 0.4000g をビーカーには かりとり，これに $\mathrm{H}_{2} \mathrm{SO}_{4}(1+1) 10 \mathrm{~m} l, \mathrm{H}_{3} \mathrm{PO}_{4} 10 \mathrm{~m} l$ を加元後述の加熱条件に注意して分解し $\mathrm{H}_{2} \mathrm{SO}_{4}(1+10)$ $30 \mathrm{ml}, \quad \mathrm{HF}(1+4) 2 \mathrm{~m} l$ を加え 2 時間加熱したのち, $\mathrm{HCl}$ 添加量を变化させ金属 $\mathrm{Al} 1.5 \mathrm{~g}$ で $\mathrm{Fe}(\mathbb{I I})$ を還元 する. $\mathrm{Al}$ の分解が終ったら， NR 指示薬 2〜3 滴と小 過剩の $\mathrm{TiCl}_{3}$ 溶液を加える. さらに NR を指示薬とし て過剩の $\mathrm{Ti}\left(\right.$ III) を $\mathrm{K}_{2} \mathrm{Cr}_{2} \mathrm{O}_{7}(0.1 \mathrm{~W} / \mathrm{V} \%)$ で酸化す る.これを約 $200 \mathrm{ml}$ にうすめてから JIS 法にしたがつ て, $\mathrm{N} / 10 \quad \mathrm{~K}_{2} \mathrm{Cr}_{2} \mathrm{O}_{7}$ 標準溶液で $\mathrm{Fe}(\mathbb{I I})$ を酸化滴定し た. その結果 $\mathrm{HCl}$ は 2〜25 $\mathrm{ml}$ ではいずれも正しい值 として定量された。また $\mathrm{HCl}$ を添加しない場合は $\mathrm{Al} の$ 分解が非常におそかった。

\section{$4 \cdot 2 \cdot 4$ 試料分解時の加熱方法}

$\mathrm{H}_{3} \mathrm{PO}$ 、 は加熱濃縮するとピロリン酸などの縮合りん 酸を生成し，これは $\mathrm{Fe}(\mathbb{I})$ と安定な錯体を形成するの で $\mathrm{Fe}(\mathbb{I I})$ の嗃元が困難となる.この影響を検討するた め実験した. JSS 801-1 インド鉱を 0.400 g をビーカー にとり， $\mathrm{H}_{2} \mathrm{SO}_{4}(1+1) 10 \mathrm{ml}$ および $\mathrm{H}_{3} \mathrm{PO}_{4} 10 \mathrm{~m} l$ を加 えて加熱し液温が所定の温度になってからその温度で一 定時間加熱を続ける. 加熱が終つたら $\mathrm{H}_{2} \mathrm{SO}_{4}(1+10) 30$ $\mathrm{m} l, \mathrm{HCl}(1+1) 10 \mathrm{~m} l, \mathrm{HF}(1+4) 2 \mathrm{~m} l$ および水 $50 \mathrm{~m} l$ を加え $80 \sim 90^{\circ} \mathrm{C}$ で 2 時間加熱し, 以下 4.2 .3 にした がつて Fe を定量した結果を Fig. 4 に示す.

Fig. 4 の結果から, 加熱温度が $210^{\circ} \mathrm{C}$ 以上になると 低值となり，加熱時間が長くなるとその傾向が増加する ことがわかつた。

\section{$4 \cdot 2.5$ 縮合りん酸の分解時間}

縮合りん酸の分解時間を検討するために, 4.2 .3 と同

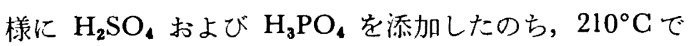
30 分間加熱してから $H F(1+4) 2 \mathrm{ml}$ 添加後の縮合り

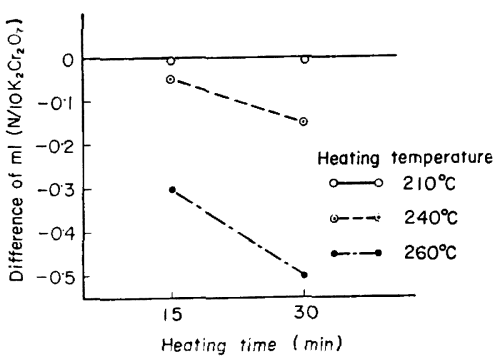

Fig. 4. Effects of heating tempernture and heating time of iron ore with $\mathrm{H}_{2} \mathrm{SO}_{4}$ and $\mathrm{H}_{3} \mathrm{PO}_{4}$ JSS-80I (INDIAN IRON ORE).

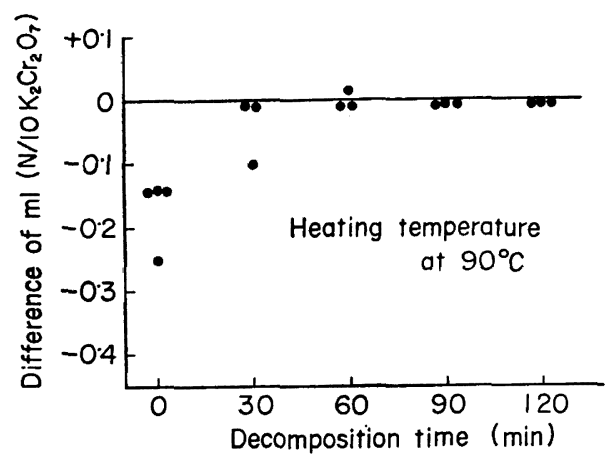

Fig. 5. Effect of decomposition time for phosphoric acid condensed (JSS 801-1 INDIAN).

几酸分解時間を变化させて実験した。

その結果は Fig. 5 に示すように加熱時間が長くなる にしたがつて負誤差が小さくなり 60 分間以上の加熱で, 正確な分析值がえられることがわかった.

\section{$4 \cdot 2 \cdot 6$ 未分解鉄量の定量}

$\mathrm{H}_{2} \mathrm{SO}_{4}$ と $\mathrm{H}_{3} \mathrm{PO}_{4}$ および $\mathrm{HF}$ では試料が完全に分解 できないおそれがある.これについて検討するため, 80 ×ッシュ以下に粉䂶した試料保 $\mathrm{H}_{2} \mathrm{SO}_{4}$ 之 $\mathrm{H}_{3} \mathrm{PO}_{4}$ を加 え， 4.2.3，4.2.4 の条件のもとで試料を分解する. 分 解後うすめて未分解残分をろ別し， $\mathrm{K}_{2} \mathrm{~S}_{2} \mathrm{O}_{7}$ で融解して からニトロソ $\mathrm{R}$ 塩吸光光度法で $\mathrm{Fe}$ を定量した．その結 果を Table 8 に示す.

Table 8. Amount of insoluble iron with $\mathrm{H}_{2} \mathrm{SO}_{4}$ and $\mathrm{H}_{3} \mathrm{PO}$.

\begin{tabular}{l|c}
\hline \multicolumn{1}{c|}{ Sample } & Fe \% \\
\hline Santa Fe & 0.033 \\
Savage River & 0.050 \\
Mt. Newman & 0.022 \\
Marcona & 0.012 \\
Dungun & 0.007 \\
Santa Barbara & 0.017 \\
Foment & 0.026 \\
\hline
\end{tabular}

\begin{tabular}{l|l}
\hline \multicolumn{1}{c|}{ Sample } & Fe \% \\
\hline Swaziland & 0.008 \\
Adrianitas & 0.020 \\
Goa & 0.009 \\
Lallap Feed 1 & 0.012 \\
Sinter Feed 2 & 0.017 \\
Sinter Feed 2 & 0.012 \\
Sinter 1 & 0.008 \\
\hline
\end{tabular}

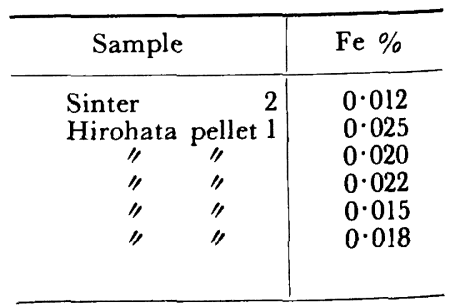


Table 9. Effects of various elements on NR method.

\begin{tabular}{|c|c|c|c|c|c|}
\hline Elements & Added mg & Added as & $\mathrm{Fe} \%$ & Difference $\%$ & Note \\
\hline V & $\begin{array}{l}0 \cdot 8 \\
1 \cdot 2 \\
1 \cdot 6 \\
2 \cdot 0 \\
3 \cdot 0 \\
4 \cdot 0\end{array}$ & $\mathrm{NH}_{4} \mathrm{VO}_{3}$ & $\begin{array}{l}64 \cdot 65 \\
64 \cdot 65 \\
64 \cdot 72 \\
65 \cdot 00 \\
65 \cdot 51 \\
66 \cdot 38\end{array}$ & $\begin{array}{l}-0.01 \\
-0.01 \\
+0.06 \\
+0.34 \\
+0.85 \\
+1.72\end{array}$ & \\
\hline $\mathrm{Cu}$ & $\begin{array}{l}0 \cdot 15 \\
0 \cdot 30 \\
0 \cdot 45 \\
0 \cdot 60 \\
1 \cdot 50\end{array}$ & $\mathrm{CuSO}_{4}$ & $\begin{array}{l}64 \cdot 58 \\
64 \cdot 64 \\
64 \cdot 51 \\
64 \cdot 65 \\
65 \cdot 00\end{array}$ & $\begin{array}{l}-0.08 \\
-0.02 \\
-0.51 \\
-0.01 \\
+0.34\end{array}$ & \\
\hline As & $\begin{array}{l}0 \cdot 125 \\
0 \cdot 250 \\
0 \cdot 375 \\
0.500\end{array}$ & $\mathrm{As}_{2} \mathrm{O}_{3}$ & $\begin{array}{l}64 \cdot 62 \\
64 \cdot 65 \\
64 \cdot 62 \\
64 \cdot 65\end{array}$ & $\begin{array}{l}-0.04 \\
-0.01 \\
-0.04 \\
-0.01\end{array}$ & \\
\hline $\begin{array}{l}\mathrm{Cr} \\
\mathrm{Ni}\end{array}$ & $\begin{array}{r}20 \\
5\end{array}$ & $\begin{array}{l}\mathrm{K}_{2} \mathrm{Cr}_{2} \mathrm{O}_{7} \\
\mathrm{NiSO}_{4}\end{array}$ & $\begin{array}{l}64 \cdot 68 \\
64 \cdot 65\end{array}$ & $\begin{array}{l}+0.02 \\
-0.01\end{array}$ & \\
\hline Co & 5 & $\mathrm{Co}(\mathrm{AC})_{2}$ & $64 \cdot 65$ & -0.01 & \\
\hline $\mathrm{Bi}$ & $\begin{array}{l}1 \\
5\end{array}$ & $\mathrm{Bi}($ I $) \mathrm{H}_{2} \mathrm{SO}_{4}$ & $\begin{array}{l}64 \cdot 72 \\
64 \cdot 65\end{array}$ & $\begin{array}{l}-0.06 \\
-0.01\end{array}$ & $*$ \\
\hline Mo & $\begin{array}{l}1 \\
5\end{array}$ & $\left(\mathrm{NH}_{4}\right)_{6} \mathrm{Mo}_{7} \mathrm{O}_{24}$ & $67 \cdot 44$ & $+2 \cdot 74$ & \\
\hline W & $\begin{array}{l}1 \\
5\end{array}$ & $\mathrm{Na}_{2} \mathrm{WO}_{4}$ & $\begin{array}{l}64 \cdot 58 \\
64 \cdot 51\end{array}$ & $\begin{array}{l}-0.08 \\
-0.15\end{array}$ & \\
\hline $\mathrm{Sb}$ & $\begin{array}{l}1 \\
5\end{array}$ & $\begin{array}{l}\mathrm{Sb}(\mathrm{I}) \\
\mathrm{HCI}\end{array}$ & $\begin{array}{l}65 \cdot 21 \\
64 \cdot 93\end{array}$ & $\begin{array}{l}+0.56 \\
+0.27\end{array}$ & \\
\hline $\mathrm{Se}$ & $\begin{array}{l}1 \\
5\end{array}$ & $\begin{array}{l}\mathrm{Se}(\mathrm{V}) \\
\mathrm{H}_{2} \mathrm{SO}_{4}\end{array}$ & $\begin{array}{c}65 \cdot 15 \\
-\end{array}$ & +0.49 & $*$ \\
\hline $\mathrm{H}_{3} \mathrm{BO}_{3}$ & 2000 & Solid & $64 \cdot 65$ & $-0 \cdot 01$ & \\
\hline F- & $\begin{array}{l}330 \\
660\end{array}$ & $\mathrm{NH}_{4} \mathrm{HF}_{2}$ & $\begin{array}{l}64 \cdot 65 \\
64 \cdot 65\end{array}$ & $\begin{array}{l}-0.01 \\
-0.01\end{array}$ & \\
\hline $\mathrm{HClO}_{4}$ & $\begin{array}{l}0.5(\mathrm{~m} l) \\
1.0(\mathrm{~m} l)\end{array}$ & & $\begin{array}{l}64 \cdot 51 \\
64 \cdot 15\end{array}$ & $\begin{array}{l}-0.15 \\
-0.51\end{array}$ & \\
\hline
\end{tabular}

* Titration is impossible

実験に用いた鉱石では，末分解の $\mathrm{Fe}$ が 0.05\%をこ えるものはなく，工程管理用の分析法としては無視でき ることがわかつた.

\section{$4 \cdot 2 \cdot 7$ 共存物質の影響}

試料中に含まれるか，または定量操作中に添加される 機会があり，本法の妨害になりそうな物質について検討 した結果を Table 9 に示す.

この結果から, 1.2 mg までのV $0.3 \mathrm{mg}$ までの $\mathrm{Cu}$, $0.5 \mathrm{mg}$ の As, $20 \mathrm{mg}$ の $\mathrm{Cr}, 5 \mathrm{mg}$ の $\mathrm{Ni}, \mathrm{Co}, \mathrm{Bi}, 2$ $\mathrm{g}$ の $\mathrm{H}_{\mathbf{2}} \mathrm{BO}_{\mathbf{3}}$ および $0.66 \mathrm{~g}$ の $\mathrm{F}$ イオンは実用上妨害と ならないことがわかった. 本法で As が妨害しないのは
$\mathrm{H}_{3} \mathrm{As}$ となって揮散するものと考えられる.

\section{3 確立した定量方法}

4.3.1 定量操作

(1) 試料 $0.4000 \mathrm{~g}$ をビーカーにはかりとり, 水 10 $\sim 15 \mathrm{ml}$ を加えて振りまぜ，かたまりをほぐし $\mathrm{H}_{2} \mathrm{SO}_{4}$ $(1+1) 10 \mathrm{ml}$ および $\mathrm{H}_{3} \mathrm{PO}_{4} 10 \mathrm{ml}$ を加え, はじめは おだやかに加熱し，硫酸白煙がかすかに発生する程度で 試料を分解する. 冷却後, $\mathrm{H}_{2} \mathrm{SO}_{4}(1+10) 30 \mathrm{ml}, \mathrm{HCl}$ $(1+1) 10 \mathrm{ml}$, および $\mathrm{HF}(1+4) 2 \mathrm{ml}$ を加え, 80〜90 ${ }^{\circ} \mathrm{C}$ に約 2 時間加熱して縮合りん酸を分解する.

（2）これに水 $50 \mathrm{ml}$ を加え，うすめたのち，金属 
$\mathrm{Al}$ 1.5 g を加え $\mathrm{Fe}($ III) を還元する. 加熱して $\mathrm{Al}$ が完 全に溶解したならば冷却する. NR 指示薬 2〜3 滴加え $\mathrm{TiCl}_{3}$ 溶液 $\mathrm{A}$ 涠色になるまで加える。（試料中に $\mathrm{Ti}$ を 含み，最初から無色の場合は $\mathrm{TiCl}_{3}$ を添加する必要がな い.) NR を指示薬として $\mathrm{K}_{2} \mathrm{Cr}_{2} \mathrm{O}_{7}(0 \cdot 1 \mathrm{~W} / \mathrm{V} \%)$ を滴 加してふりまぜ青紫色を呈した点で止める.

（3）水で約 $200 \mathrm{ml}$ にうすめてジフェニルアミンス ルホン酸 3〜4 滴を加え, $\mathrm{N} / 10 \mathrm{~K}_{2} \mathrm{Cr}_{2} \mathrm{O}_{7}$ 標準溶液で $\mathrm{Fe}$ （II）を滴定する.

\section{4 実際試料の分析結果}

確立した方法により各種標準試料を分析した 結果を Table 10 に示す．また各種鉄鉱石を用い JIS 法と比較 した結果を Table 11 に示す.

Table 10. Results of standard samples by NR method.

\begin{tabular}{|c|c|c|c|}
\hline Sample & $\begin{array}{l}\text { Standard } \\
\text { value } \\
\text { T. Fe } \%\end{array}$ & $\mathrm{~T}, \mathrm{Fe} \%$ & Error \\
\hline $\begin{array}{l}\text { JSS } 800-1 \\
\text { LOMPIN } \\
\text { Iron ore }\end{array}$ & $\begin{array}{c}62 \cdot 85 \\
(\mathrm{Cu} 0.064)\end{array}$ & $\begin{array}{l}62 \cdot 83 \\
62 \cdot 90\end{array}$ & $\begin{array}{l}-0.02 \\
+0.05\end{array}$ \\
\hline $\begin{array}{l}\text { JSS } 801-1 \\
\text { INDIAN } \\
\text { Iron ore }\end{array}$ & $64 \cdot 66$ & $\begin{array}{l}64 \cdot 65 \\
64 \cdot 65\end{array}$ & $\begin{array}{l}-0.01 \\
-0.01\end{array}$ \\
\hline $\begin{array}{l}\text { JSS } 801-1 \\
\text { TEXADA } \\
\text { Iron ore }\end{array}$ & $\begin{array}{c}64 \cdot 87 \\
(\mathrm{Cu} 0.046)\end{array}$ & $\begin{array}{l}64 \cdot 86 \\
64 \cdot 86\end{array}$ & $\begin{array}{l}-0.01 \\
-0.01\end{array}$ \\
\hline $\begin{array}{l}\text { JSS } 850-1 \\
\text { MARCONA } \\
\text { PELLET } \\
\text { Iron ore }\end{array}$ & $66 \cdot 77$ & $\begin{array}{l}66 \cdot 78 \\
66 \cdot 74\end{array}$ & $\begin{array}{l}+0.01 \\
-0.03\end{array}$ \\
\hline $\begin{array}{l}\text { NSS } 801-1 \\
\text { HAMERSLEY } \\
\text { Iron ore }\end{array}$ & $67 \cdot 45$ & $\begin{array}{l}67 \cdot 44 \\
67 \cdot 58\end{array}$ & $\begin{array}{l}-0.01 \\
+0.13\end{array}$ \\
\hline $\begin{array}{l}\text { NSS } 801 \\
\text { SANTA FE } \\
\text { Iron ore }\end{array}$ & $59 \cdot 21$ & $\begin{array}{l}59 \cdot 20 \\
59 \cdot 20\end{array}$ & $\begin{array}{l}-0.01 \\
-0.01\end{array}$ \\
\hline $\begin{array}{l}\text { ISS } 830-1 \\
\text { PHILIPPINE } \\
\text { SAND } \\
\text { Iron ore }\end{array}$ & $\begin{array}{c}60.53 \\
(\mathrm{~V} 0.31)\end{array}$ & $\begin{array}{l}60 \cdot 53 \\
60 \cdot 46\end{array}$ & $\begin{array}{l}0 \\
-0.07\end{array}$ \\
\hline
\end{tabular}

この結果から，標準試料の標準值および JIS 法とよく 一致しており，工程管理分析法として十分使用できるこ とがわかる.なお，JSS 801-1 インド鉱を用い $n=20$ の繰返し精度を測定した結果， $\sigma=0.04 \% \mathrm{Fe}$ であつた。

\section{5 作業性}

工程管理分析を目的としたときは，操作上の緩急の度 合はあるものの，標準的操作によるならば 1 回の所要時 間は約 3 時間であり，1日（8時間）では 25 ケの定量 ができる.ただ多数試料の並行処理に際しては加熱板の 温度分布に十分な注意をむけ，過熱しないようにするこ とが大切である。

\section{5. 結}

言

水銀塩を用いない鉄鉱石中の全鉄定量方法の開発を目 的として検討を行ない実用性に富む方法としてまとめる ことに成功した． $\mathrm{Fe}($ III) を還元し過剩還元戍の定量的 酸化の判定に有機采酸化還元指示薬を応用し，実用しう ることが確められた. $\mathrm{Fe}$ (II) の酸化滴定方法は JIS と 同じ重クロム酸カリウム滴定法とした. 全操作を通じ大 気雲囲気で実施できるのを特色とする.

$\mathrm{HCl}$ で分解した試料溶液では, $\mathrm{SnCl}_{2}$ を用いて大部分 の $\mathrm{Fe}(\mathbb{I I})$ を還元し, 少量の $\mathrm{Fe}(\mathbb{I I})$ は $\mathrm{TiCl}_{3}$ を用い て還元する. 過剩の $\mathrm{Ti}$ (III) はインジゴテトラスルフォ ン酸を指示薬として酸化する. $\mathrm{Ti}(\mathbb{I I})$ の酸化時には, $\mathrm{Mn}(\mathbb{I})$ の存在が不可欠であるとともに， $\mathrm{Cu}, \mathrm{V}$ の妨 害度合も Mn 量と関係することがわかった.

この定量方法では，As の $1 \mathrm{mg}$ は通常妨害せず， Cu の $2 \mathrm{mg}, \mathrm{V}$ の $3 \mathrm{mg}$ までは簡単な手段で妨害を除くこ とができる.

この方法の正確さは, 28 種の鉄鈗石について JIS 法1) と新方法との定量結果の差, $\bar{d}=0.0033 \% \mathrm{Fe}$ で新方法が わずかに高目であつたが，個々のデータの照合では， 0.04\% をこえる差は生じなかつた、鉄鉱石標準試料を 定量した結果では $\pm 0.04 \%$ 以内で一致した。作業性は 良好で試料液の準備ができた時点より 5 分間で定量は終 る.

Table 11. Comparison of analytical results by NR method to JIS method.

\begin{tabular}{|c|c|c|c|c|c|}
\hline \multirow{2}{*}{\begin{tabular}{l}
\multicolumn{1}{c}{ Sample } \\
Marcona Slurry \\
Goldsworthy \\
Sase Goa \\
Dempo \\
Savage River pellet \\
Bailadila \\
Hamersley pellet \\
Yampi Sound
\end{tabular}} & $\begin{array}{c}\text { JIS method \% } \\
69 \cdot 34 \\
62 \cdot 90\end{array}$ & \multicolumn{2}{|c|}{ NR method $\%$} & \multicolumn{2}{|c|}{ Error \% } \\
\hline & $\begin{array}{l}69 \cdot 34 \\
62 \cdot 90 \\
64 \cdot 18 \\
63 \cdot 25 \\
67 \cdot 32 \\
64 \cdot 65 \\
63 \cdot 62 \\
67 \cdot 19\end{array}$ & $\begin{array}{l}69 \cdot 44 \\
62 \cdot 81 \\
64 \cdot 25 \\
63 \cdot 28 \\
67 \cdot 24 \\
64 \cdot 52 \\
63 \cdot 60 \\
67 \cdot 17\end{array}$ & $\begin{array}{l}69 \cdot 37 \\
62 \cdot 81 \\
64 \cdot 25 \\
63 \cdot 21 \\
67 \cdot 31 \\
64 \cdot 57 \\
63 \cdot 64 \\
67 \cdot 24\end{array}$ & $\begin{array}{l}+0.10 \\
-0.09 \\
+0.07 \\
+0.03 \\
-0.08 \\
-0.13 \\
-0.02 \\
-0.02\end{array}$ & $\begin{array}{l}+0.03 \\
-0.09 \\
+0.07 \\
-0.04 \\
-0.01 \\
-0.08 \\
+0.02 \\
+0.05\end{array}$ \\
\hline
\end{tabular}


Table 12. Effect of particle size of iron ores on dissolution.

\begin{tabular}{|c|c|c|c|c|c|c|}
\hline Particle size (mesh) & \multicolumn{3}{|c|}{$60>$ Somple $>100 \quad n=5$} & \multicolumn{3}{|c|}{ Sample $>200 \quad n=2$} \\
\hline Iron ores $\quad \begin{array}{r}\text { Dissolution } \\
\text { method }\end{array}$ & $\begin{array}{l}\text { JIS method } \\
\text { (A) }\end{array}$ & $\begin{array}{c}\text { Dissolution } \\
\text { with } \mathrm{H}_{3} \mathrm{PO}_{4}, \\
\mathrm{H}_{2} \mathrm{SO}_{4}(\mathrm{~B})\end{array}$ & (B) $\stackrel{d}{-(A)}$ & $\begin{array}{l}\text { JIS method } \\
\text { (A) }\end{array}$ & $\begin{array}{c}\text { Dissolution } \\
\text { with } \mathrm{H}_{3} \mathrm{PO}_{4} \text {, } \\
\mathrm{H}_{2} \mathrm{SO}_{4} \text { (B) }\end{array}$ & (B) $\stackrel{d}{-(A)}$ \\
\hline $\begin{array}{l}\text { Marcona } \\
\text { Swaziland } \\
\text { Dempo } \\
\text { Yampi Sound } \\
\text { Mt. Newnian } \\
\text { Hamersley } \\
\text { Santa Fe }\end{array}$ & $\begin{array}{r}66 \cdot 28 \\
62 \cdot 37 \\
62 \cdot 29 \\
66 \cdot 92 \\
64 \cdot 72 \\
64 \cdot 93 \\
* 63 \cdot 46\end{array}$ & $\begin{array}{r}66 \cdot 36 \\
62 \cdot 32 \\
62 \cdot 19 \\
66 \cdot 06 \\
64 \cdot 67 \\
64 \cdot 80 \\
* 62 \cdot 98\end{array}$ & $\begin{array}{r}0.08 \\
-0.05 \\
-0.10 \\
0.14 \\
-0.05 \\
-0.13 \\
-0.48\end{array}$ & $\begin{array}{l}69 \cdot 59 \\
63 \cdot 93 \\
63 \cdot 26 \\
65 \cdot 87 \\
64 \cdot 98 \\
64 \cdot 94 \\
56 \cdot 72\end{array}$ & $\begin{array}{l}69 \cdot 69 \\
63 \cdot 85 \\
63 \cdot 14 \\
65 \cdot 92 \\
65 \cdot 04 \\
64 \cdot 80 \\
56 \cdot 56\end{array}$ & $\begin{array}{r}0.10 \\
-0.08 \\
-0.12 \\
0.05 \\
0.06 \\
-0.14 \\
-0.16\end{array}$ \\
\hline
\end{tabular}

* $n=12$

別法として試料を硫酸とりん酸とを用いて分解すると きは， $\mathrm{Al}$ を還元剤として用い，残る $\mathrm{Fe}$ (II) を $\mathrm{TiCl}_{3}$ を用いて還元する. 過剩の $\operatorname{Ti}(\mathbf{I})$ はニュートラルレッ ドを指示薬として酸化する。

この方法では, As は妨害せずV 1.2 mg 以下も妨害 しない. 鉄鉱石標準試料の定量結果では $\pm 0.13 \%$ 以内 で一致した. 同一試料の 20 回のくり返し定量結果では $\sigma=0.04 \%$ であった. この方法での処理能力は 1 人 1 日 25 定量である.

\section{文献}

1) JIS M 8212-(1971) 鉄鉱石中の全鉄定量方法, 塩化第一すず這元重クロム酸カリウム滴定法

2 ) 同上, 硫化水素還元重クロム酸カリウム滴定法

3 ) 日本分析化学会編: 分析化学便覧, (1961), p. 343，(丸善)

4 ) 㚼，萩原，㴔見：分析化学，22 (1971), p. 886

5 ) 脇野, 村田, 尾松: 分析化学, 20 (1971), p.395

6) 日本化学会編: 化学便覧, (1965), p. 1309 (丸 善)
7 ) H. FREISER, Q. FRENANDO（藤永太一郎，関戸栄 訳)：イオン平衡, (1971)，p. 261，263，264(化 学同人)

8 ) 石橋雅義: 定量分析実駗法, 普通編, (1950), p. 360 (富山房)

9 ) 吉村寿人：PH の理論とその測定法， (1950), p. 103，462 (丸善)

10)分析化学辞典編集委員会: 分析化学辞典, (1971) p. 1744 (共立出版)

11）JIS M 8212（1958）鉄鉱石中の鉄分析法

12）富士製鉄 (株) 広畑製鉄所：鉄共研化学分析分科 会, CA-97 (1969)

\section{討論}

[質問] 住友金属中研, 新見敬古

$\mathrm{H}_{3} \mathrm{PO}$ 、を用いる試料分解法では試料粒度が粗大にな ると，全鉄定量值に低目の傾向がでるといわれているが どうか.

[回答]この点につき実験を行なつた結果をTable 12 に示す. 指摘のとうり, 粗粒試料では標準的な方法 ${ }^{1)}$ くらべて低目に定量される試料があつた. 試料分解時の 加熱条件によるものと考えている. 